\title{
Accelerating Seed Germination and Juvenile Growth of Sorghum (Sorghum bicolor L. Moench) to Manage Climate Variability through Hydro-Priming
}

\author{
Siaka Dembélé ${ }^{1, *(\mathbb{D}}$, Robert B. Zougmoré ${ }^{2}$, Adama Coulibaly ${ }^{1}$, John P. A. Lamers ${ }^{3}$ and Jonathan P. Tetteh ${ }^{4}$ \\ 1 Institut d'Economie Rurale (IER), Agricultural Research Station of Cinzana (SRAC), \\ Ségou BP 214, Mali; adamacz097@gmail.com \\ 2 CGIAR Research Program on Climate Change, Agriculture and Food Security (CCAFS), International Crops \\ Research Institute for the Semi-Arid Tropics (ICRISAT), Bamako BP 320, Mali; r.zougmore@cgiar.org \\ 3 ZEF C - Department of Ecology and Natural Resources Management/Center for Development Research, \\ University of Bonn, Genscherallee, 53115 Bonn, Germany; jlamers@uni-bonn.de \\ 4 Department of Crop Science/School of Agriculture, College of Agriculture and Natural Sciences, \\ University of Cape Coast (UCC), Accra P.O. Box 5007, Ghana; jptetteh2@yahoo.com \\ * Correspondence: siakadembele373@gmail.com
}

Citation: Dembélé, S.; Zougmoré, R.B.; Coulibaly, A.; Lamers, J.P.A.; Tetteh, J.P. Accelerating Seed Germination and Juvenile Growth of Sorghum (Sorghum bicolor L. Moench) to Manage Climate Variability through Hydro-Priming. Atmosphere 2021, 12, 419. https://doi.org/10.3390/ atmos12040419

Academic Editor:

Andreas Matzarakis

Received: 4 March 2021

Accepted: 20 March 2021

Published: 24 March 2021

Publisher's Note: MDPI stays neutral with regard to jurisdictional claims in published maps and institutional affiliations.

Copyright: (c) 2021 by the authors. Licensee MDPI, Basel, Switzerland. This article is an open access article distributed under the terms and conditions of the Creative Commons Attribution (CC BY) license (https:// creativecommons.org/licenses/by/ $4.0 /)$.

\begin{abstract}
Agriculture in Mali, a country in Sahelian West Africa, strongly depends on rainfall and concurrently has a low adaptive capacity, making it consequently one of the most vulnerable regions to climate change worldwide. Since early-season drought limits crop germination, and hence growth, ultimately yield during rain-fed depending on production is commonly experienced nowadays in Mali. Germination and establishment of key crops such as the staple sorghum could be improved by seed priming. The effects of hydro-priming with different water sources (e.g., distilled, tap, rain, river, well water) were evaluated respectively for three priming time durations in tepid e.g., at $25^{\circ} \mathrm{C}$ $\left(4,8\right.$, and $12 \mathrm{~h}$ ) and by hot water at $70^{\circ} \mathrm{C}$ (in contrast to 10, 20, and $30 \mathrm{~min}$.) in 2014 and 2015. Seed germination and seedling development of nine sorghum genotypes were monitored. Compared to non-primed seed treatments, hydro-priming significantly $[p=0.01]$ improved final germination percentage, germination rate index, total seedling length, root length, root vigor index, shoot length, and seedling dry weight. The priming with water from wells and rivers resulted in significant higher seed germination (85\%) and seedling development, compared to the three other sources of water. Seed germination rate, uniformity, and speed were enhanced by hydro-priming also. It is argued that hydro-priming is a safe and simple method that effectively improve seed germination and seedling development of sorghum. If used in crop fields, the above most promising genotypes may contribute to managing early season drought and avoid failure of seed germination and crop failure in high climate variability contexts.
\end{abstract}

Keywords: hydro-priming; sorghum; resilience; early season drought; semi-arid; West Africa

\section{Introduction}

The farming population in the West Africa Sahelian regions experiences frequent droughts during the unimodal rainy season. Especially at the onset of the growing season this increases risks at the sowing and juvenile growth period. More and more, farmers experience rainfall amounts enough to seed but insufficient to warrant further growth, whilst gradually the periods between rainfall events grow irregular, more highly endangering crop establishment. In addition, high temperatures are common at the onset of the growing season provoking increased soil evaporation and hence moisture deficiencies, of which $90-95 \%$ usually occurs in the 5-10 cm topsoil layer [1], that is the usual key depth for crop sowing. Under such moisture-poor condition, it appears important to improve the germination speed and rate to permit seedlings using as fast as possible any available soil 
moisture $[2,3]$. To this end, seed priming is regarded as one way to secure and improve germination in a bid to increase crop yield under such drought-prone conditions [4,5].

Seed priming is defined as a pre-sowing treatment that exposes dry seeds to a certain solution that allows partial hydration, but consequently not a complete germination yet [6]. Although the germination is triggered before actual sowing, the idea of priming is to initiate the metabolic activities that prepare seeds for radical protrusion [7-9]. It recurrently has been stated that seed priming thus can accelerate and improve germination and early seedling growth, which is particularly appropriate under the typical drought stress conditions as occurring at the onset of the season in the Sahelian zone of West Africa $[10,11]$. Various priming procedures have been developed successfully, all aiming at increasing the speed of seed germination $[10,12]$, and secure emergence through improved water absorption capacity $[13,14]$.

Well-known, practical efficient priming techniques include (a) hydro-priming where seeds are soaked in a fluid such as water, (b) osmo-priming where seeds are soaked into an osmotic solution such as polyethylene glycol 6000 (PEG-6000), (c) halo-priming where seeds are soaked in salt solutions, and (d) priming with growth-stimulating hormones. The beneficial effects of priming have been demonstrated for various field crops such as maize [15,16], sunflower [17], and others (soybean, wheat, lentil, chickpea, mungbean, cowpea, etc.) [18]. Previous findings underscored that the success of seed priming was determined by the complex interaction of plant species, the water potentiality (i.e., water chemical composition) of the priming agent, the duration of priming, the solution temperature during soaking, seed vigor, and previous storage conditions of the primed seeds [15]. Parera and Cantliffe emphasized that hydro-priming is the simplest approach to hydrating seeds and concurrently minimize the use of chemicals. However, the key is that imbibed seeds show a decreased lag period before radical emergence, which is initially reduced, but finally improves the rate and uniformity of germination [18,19]. Furthermore, previous findings underlined that hydro-priming may improve field emergence and ensured early flowering and harvesting under water stress conditions, especially in dry areas [15,20]. Hydro-priming, therefore, is a recognized means to reduce overall germination time, get synchronized germination, improve germination rates, and improve seedling establishment in many crops including maize, soybean, wheat, lentil, chickpea, mungbean, cowpea, etc. [20]. Soaking seeds of sorghum, rice, maize, and cowpea in water and planting presoaked seeds on the same day (presoaking treatment), increased germination rate, and improved seedling emergence [21,22].

The extended documentation on priming underlined the different parameters and indicators used to assess the performance of priming as recurrently explained in handbooks and laboratory manuals [23]. Whilst some parameters such as germination rate index (GRI), seedling vigor index (SVI), and germination index have been used sporadically [24,25], most assessment studies typically used parameters such as final germination percentage, mean germination time, seedling dry weight, and root vigor index [2,23,26-29]. Despite all previous reports recommending such interventions to the Malian farmer it is pertinent to confirm the positive impact of hydro-priming as an effective and efficient means to combat early season drought stress on key staples in Mali given the well-known impact of the inhibition solution [15], presoaking duration [2,20] crops and cultivars [2], and temperature of the soaking solution [2,15]. This paper aims to therefore assess the hydro-priming effects on nine Sorghum cultivars by using different sources of water and priming duration under controlled conditions in Mali.

\section{Materials and Methods}

The study was conducted in the Agronomy laboratory of the Agricultural Research Station of Cinzana (Longitude: $5^{\circ} 57^{\prime} \mathrm{W}$, Latitude: $13^{\circ} 15^{\prime} \mathrm{N}$, and Altitude: $280 \mathrm{~m}$ ), located at the Institut d'Economie Rurale (IER) Bamako, Mali. Three out of the nine sorghum cultivars examined were obtained directly from farmers, the six remainders were released 
materials by the IER national sorghum breeding program whilst the variety Banidoka was used as a reference, as each variety had its known characteristics (Table 1).

Table 1. Characteristics of the selected sorghum cultivars used during the screening experiments.

\begin{tabular}{|c|c|c|c|c|c|}
\hline Sorghum Variety & Sorghum Cultivars & Days to Mature & Overall Cultivar Type & $\begin{array}{l}\text { Optimum Rainfall } \\
\text { Requirement (mm) }\end{array}$ & Source \\
\hline Banidoka & Guinea & 120 & Land race & $600-800$ & Farmer \\
\hline CSM63E & Guinea & 100 & Cultivar & $400-700$ & IER \\
\hline Nieleni & Caudatum-Guinea & 110 & Hybrid & 700-1000 & IER \\
\hline Saba-soto & Caudatum & 100 & Land race & * Receding flood & Farmer \\
\hline Saba-tienda & Durra & 90 & Land race & * Receding flood & Farmer \\
\hline Seguifa & Durra & 100 & Cultivar & $400-700$ & IER \\
\hline Sewa & Caudatum-Guinea & 110 & Hybrid & 800-1000 & IER \\
\hline Tiandougou & Guinea & 120 & Cultivar & $800-1000$ & IER \\
\hline Tiandougou-coura & Caudatum-Guinea & 120 & Cultivar & $800-1000$ & IER \\
\hline
\end{tabular}

Source: $[29,30] *$ Grown after flood water has receded.

Aside from referring the performance of eight sorghum cultivars to the wide-spread cultivar Banidoka, the effect of priming parameters on all nine Sorghum cultivars was assessed by comparing the impact of priming with untreated sorghum seeds (these served as controls). Given the effect of the soaking solution on hydro-priming [2,7]. The effect of the water sources on priming performance was assessed by comparing five sources of water including distilled, rain, river, tap, and well water which all are available in the country. In addition, three different priming durations were compared for heated and tepid water. Given the impact of soaking time [19]. The soaking durations compared included 10, 20 , and $30 \mathrm{~min}$, whilst in the case of the tepid water, the seeds were soaked for 4,8 , and $12 \mathrm{~h}$ (Table 2). Seeds were soaked in the selected water sources which had been treated: either as tepid water at $25^{\circ} \mathrm{C}$ or in water previously heated at $70^{\circ} \mathrm{C}$. Consequently, the experiment consisted out of 40 treatments on nine sorghum varieties, water sources (6 levels) soaking duration in tepid water (4 levels) and in hot water (4 levels), hence all in all we dealt with 40 treatments and combinations thereof (Table 2).

Table 2. Hydro-priming treatment combinations.

\begin{tabular}{cccccccc}
\hline $\begin{array}{c}\text { Water } \\
\text { Sources }\end{array}$ & \multicolumn{3}{c}{$\begin{array}{c}\text { Duration (min.) of Seed } \\
\text { Submergence in Hot Water at }\end{array}$} & \multicolumn{3}{c}{$\begin{array}{c}\text { Duration (min.) of Seed Submergence } \\
\text { in Water at Room Temperature }\left(25{ }^{\circ} \mathbf{C}\right)\end{array}$} \\
\hline & 0 & 10 & 20 & 30 & 240 & 480 & 720 \\
\hline Distilled & $\mathrm{X}$ & $\mathrm{X}$ & $\mathrm{X}$ & $\mathrm{X}$ & $\mathrm{X}$ & $\mathrm{X}$ & $\mathrm{X}$ \\
Rain & $\mathrm{X}$ & $\mathrm{X}$ & $\mathrm{X}$ & $\mathrm{X}$ & $\mathrm{X}$ & $\mathrm{X}$ & $\mathrm{X}$ \\
River & $\mathrm{X}$ & $\mathrm{X}$ & $\mathrm{X}$ & $\mathrm{X}$ & $\mathrm{X}$ & $\mathrm{X}$ & $\mathrm{X}$ \\
Tap & $\mathrm{X}$ & $\mathrm{X}$ & $\mathrm{X}$ & $\mathrm{X}$ & $\mathrm{X}$ & $\mathrm{X}$ & $\mathrm{X}$ \\
Well & $\mathrm{X}$ & $\mathrm{X}$ & $\mathrm{X}$ & $\mathrm{X}$ & $\mathrm{X}$ & $\mathrm{X}$ & $\mathrm{X}$ \\
\hline
\end{tabular}

\subsection{Description of Hydro-Priming in Tepid and Hot Water}

Each seed treatment was soaked in an open container about $125 \mathrm{~mL}$ and kept at room temperature for the duration of the priming.

Prior to the implementation of the soaking treatments, all seeds were surface-sterilized with $5 \%$ sodium hypochlorite $(\mathrm{NaOCl})$ for $5 \mathrm{~min}$ to avoid fungal infections. This treatment was followed by washing, with distilled water, which occurred twice to wash off the chemicals according to previous studies [31].

Twenty-five of the pre-treated seeds of each variety were placed in a 9-cm diameter Petri dish on two Whatman filter papers that were moistened at the onset of the experiment and on the fourth day after sowing with $3 \mathrm{~mL}$ of test solution obtained from each of the five water sources (Table 2). The seeds of the control type 1 treatment were moistened with $3 \mathrm{~mL}$ distilled water at the onset and at the 4th day after sowing. Throughout the 
duration of the experiment, the petri dishes with seeds were kept inside the germinator. The temperature of both the germinator and room were recorded daily.

\subsection{Evaluation of Hydro-Priming in Tepid Water}

The effect of priming on the nine Sorghum cultivars in tepid water was assessed by comparing them with the untreated seeds of the same cultivar (control). The effect of the water source on priming performance was assessed by comparing the five sources of water that farmers in Mali could have access to, including distilled, rain, river, tap, and well water. In the case of the solution temperature, in case of tepid water priming, seeds had been soaked for 4,8 , and $12 \mathrm{~h}$. Hence, each of the seeds of the 9 sorghum varieties were subjected to 40 different priming treatments. There was a control treatment where no priming was carried out for each variety.

\subsection{Evaluation of Hydro-Priming in Hot Water}

The effects of different procedures of hydro-priming on the germination and seed establishment performance of nine sorghum varieties were evaluated while using 6 water sources soaking duration in tepid water (4 levels) and in hot water (4 levels). The water used was from the five aforementioned water sources e.g., distilled, tap, rain, river, and well water. The water used for presoaking was heated first to $70^{\circ} \mathrm{C}$ before use. Seeds were submerged in warm water for 10-, 20-, or 30-min duration before sowing in petri dish (Table 2). A factorial arranged completely randomized design with three replications was used to assess the impact of the priming treatments through key assessment parameters (Table 3).

Table 3. Seed germination assessment parameters.

\begin{tabular}{|c|c|c|c|c|}
\hline Assessment Parameter & Abbreviation & Calculation Base & $\begin{array}{c}\text { Explanation of } \\
\text { Assessment Parameter }\end{array}$ & Source \\
\hline Germination Percentage & GP $(\%)$ & $\begin{array}{c}\mathrm{GP}=(\text { Number of seeds } \\
\text { germinated }) /(\text { number of seeds } \\
\text { sown }) \times 100\end{array}$ & $\begin{array}{l}\text { (Number of total seeds } \\
\text { germinated over the } \\
\text { number of total seeds sown } \\
\text { time hundred). }\end{array}$ & [23] \\
\hline Mean Germination Time & MGT (Days) & $\mathrm{MGT}=\left(\sum(\mathrm{Dn}) /\left(\sum \mathrm{n}\right)\right.$ & $\begin{array}{l}\mathrm{n} \text { is the number of seeds } \\
\text { germinated on each day } \\
\text { counted, whilst } \mathrm{D} \text { is the } \\
\text { day of counting } \mathrm{n} \text {. }\end{array}$ & [26] \\
\hline Root Vigor Index & RVI & $\mathrm{RVI}=\mathrm{RL} \times \mathrm{GP}$ & $\begin{array}{c}\mathrm{RL} \text { is the root length }(\mathrm{cm}) \text {, } \\
\text { and GP is the germination } \\
\text { percentage. }\end{array}$ & \\
\hline Germination Rate Index & GRI (\%/day) & $\mathrm{GRI}=\sum(\mathrm{GP} 1+\mathrm{GP} 2 \ldots \mathrm{GPn}) / \mathrm{n}$ & $\begin{array}{l}\text { Summation of the } \\
\text { germination percentage at } \\
\text { each day (GP) divided by } \\
\text { the total days (n) of } \\
\text { germination. }\end{array}$ & [32] \\
\hline Seedling Dry Weight & SDW (g/plant) & $\begin{array}{l}\text { Dry samples weighted and } \\
\text { expressed in } \mathrm{g} .\end{array}$ & $\begin{array}{l}\text { Weight determined after } \\
\text { drying seedling samples at } \\
105^{\circ} \mathrm{C} \text { for } 24 \mathrm{~h} \text {. }\end{array}$ & [33] \\
\hline
\end{tabular}

\subsection{Statistical Analysis}

Data were analyzed through an analysis of variance (ANOVA) using GenStat nine edition version 9.2.0 (2007). As part of the analyses all data were checked for normality and normal distribution before being subjected to ANOVA. The means of germination percentage, mean germination time, germination rate index, seedling vigor index, root vigor index, and seedling dry weight were compared with those of the treatments of the nine sorghum varieties, water sources (6 levels) soaking duration in tepid water (4 levels) and in hot water (4 levels). Multiple comparisons among treatments means were considered 
significantly different at $p \leq 0.05$ according to The Fisher's Protected Least Significant Difference (LSD) for means separation [34]. Water is a basic requirement for germination. It is essential for enzyme activation, breakdown, translocation, and use of reserve storage material [35]. Every enzyme shows maximum activity at an optimum $\mathrm{pH}$. Their activity is slow above or below the optimum $\mathrm{pH}$. Enzymes have active sites where the substrates bind. These active sites are damaged or in other words their shape is changed by changing the $\mathrm{pH}$. Substrates no longer fit the active site and the reaction does not occur. A pH of about 7 is the optimum and as the $\mathrm{pH}$ moves further away from the optimum $\mathrm{pH}$ the enzyme activity starts to slow down. Given the potential impact of the chemical composition of the soaking solution on the germination performance [36], samples of each water source used were sent for chemicals analysis in the laboratory in 2014 and 2015.

\section{Results}

\subsection{Chemical Composition of Sources of Water}

Although not analyzed statistically because of limited time, we observed that chemical composition varied according to water sources. In general, highest concentration of total dissolved solid (TDS) was found in river and well water followed by tap, rain, and distilled water, respectively (Table 4). The $\mathrm{pH}$ was high in river (7.7) and well (7.2) water, whilst lowest in tap (6.5), rain (6.7), and distilled (6.7) water.

Table 4. Chemical composition of various water sources.

\begin{tabular}{cccccc}
\hline Parameters & Distilled & Rain & River & Tap & Well \\
\hline $\mathrm{pH}$ & 6.7 & 6.7 & 7.7 & 6.5 & 7.2 \\
\hline $\mathrm{EC}\left(25^{\circ} \mathrm{C}\right) \mu \mathrm{S} \mathrm{cm}{ }^{-1}$ & 6.5 & 9.5 & 87.5 & 40.5 & 181.5 \\
$\mathrm{Hardness}(\mathrm{mg} / \mathrm{L})$ & 3.5 & 5 & 38 & 18 & 63 \\
$\mathrm{CaCO}_{3}(\mathrm{mg} / \mathrm{L})$ & 2.0 & 3.5 & 38.5 & 16.0 & 63.5 \\
$\mathrm{TDS}^{\circ}\left(105^{\circ} \mathrm{C}\right)(\mathrm{mg} / \mathrm{L})$ & 8.9 & 13.0 & 82.9 & 61.6 & 139.7 \\
Calcium, $\mathrm{Ca}^{2+}(\mathrm{mg} / \mathrm{L})$ & 0.5 & 0.5 & 8.5 & 2.8 & 17.5 \\
Magnesium, $\mathrm{Mg} 2+(\mathrm{mg} / \mathrm{L})_{\text {Sodium, } \mathrm{Na}+(\mathrm{mg} / \mathrm{L})}^{1.0}$ & 0.9 & 4.1 & 2.6 & 4.7 \\
Potassium, $\mathrm{K}+(\mathrm{mg} / \mathrm{L})$ & 0.2 & 0.2 & 3.4 & 3.3 & 7.3 \\
Bicarbonates, $\mathrm{HCO}_{3}(\mathrm{mg} / \mathrm{L})$ & 2.6 & 0.7 & 2.7 & 1.4 & 8.3 \\
${\text { Sulphates, } \mathrm{SO} 4^{2-}(\mathrm{mg} / \mathrm{L})}^{-}$ & 0.6 & 0.4 & 46.9 & 19.1 & 77.5 \\
Chlorine, $\mathrm{Cl}^{-}(\mathrm{mg} / \mathrm{L})$ & 0.3 & 0.3 & 5.2 & 3.4 & 2.3 \\
Nitrates, $\mathrm{NO}_{3}-(\mathrm{mg} / \mathrm{L})$ & 0.1 & 0.1 & 0.9 & 2.6 & 1.9 \\
Copper, $\mathrm{Cu}^{2}+(\mathrm{mg} / \mathrm{L})$ & 0.0 & 0.1 & 0.0 & 0.0 & 0.6 \\
Zinc, $\mathrm{Zn}(\mathrm{mg} / \mathrm{L})$ & 0.0 & 0.1 & 0.0 & 0.0 & 0.0 \\
\hline
\end{tabular}

Values are means for chemical composition in 2014 and 2015.

The TDS influence $\mathrm{pH}$ level towards alkalinity and was higher in well $\left(139.7 \mathrm{mg} \mathrm{L}^{-1}\right)$, river $\left(82.9 \mathrm{mg} \mathrm{L}^{-1}\right)$ while it was low in rain $\left(13.0 \mathrm{mg} \mathrm{L}^{-1}\right)$ and distilled water $\left(8.9 \mathrm{mg} \mathrm{L}^{-1}\right)$. The concentration of calcium carbonate was high in well and river water lower in rain and distilled water (Table 4). The highest concentration of calcium was found in well water $\left(17.5 \mathrm{mg} \mathrm{L}^{-1}\right)$ followed by river water $\left(8.5 \mathrm{mg} \mathrm{L}^{-1}\right)$, and the remaining was low. The Bicarbonate $\left(\mathrm{HCO}_{3}\right)$ concentration was also higher in well $\left(77.5 \mathrm{mg} \mathrm{L}^{-1}\right)$ and river water $\left(46.9 \mathrm{mg} \mathrm{L}^{-1}\right)$ (Table 4$)$. Micronutrients copper and zinc were slightly present only in rainwater which suggests the side effect on seed growth parameters. The presence of these micronutrients seems to inhibit seed germination and growth parameters which go beyond the scope of this study (Table 4 ).

\subsection{Effect of Tepid Hydro-Priming on Seed Germination and Seedling Growth Parameters} 3.2.1. Germination Percentage (GP)

The GP was significantly affected by varieties in tepid water $(p=0.01)$, while water sources, priming duration, and their interaction were not significantly different for germination percentage (Table 5). Among varieties, CMS63E, Banidoka, followed by Saba-tienda and Seguifa were statistically higher and different from other varieties in 
tepid water (Table 5) while Tandougou was significantly different from Nieleni, Sewa, Tiandougou-Coura, and Saba-Soto.

Table 5. Effect of tepid water priming at different durations and with water from different sources on seed germination and other growth parameters of nine varieties of sorghum.

\begin{tabular}{|c|c|c|c|c|c|}
\hline \multirow{2}{*}{$\begin{array}{c}\text { Treatments } \\
\text { Variety }\end{array}$} & \multicolumn{5}{|c|}{ Assessment Parameters } \\
\hline & GP & MGT & GRI & RVI & SDW \\
\hline Banidoka & $99.0 \pm 1.12$ & $4.6 \pm 0.02$ & $96.2 \pm 1.23$ & $532.7 \pm 15.30$ & $0.13 \pm 0.01$ \\
\hline CSM63E & $99.2 \pm 1.12$ & $4.5 \pm 0.02$ & $98.5 \pm 1.23$ & $436.0 \pm 18.90$ & $0.12 \pm 0.01$ \\
\hline Nieleni & $87.2 \pm 1.12$ & $4.6 \pm 0.02$ & $84.0 \pm 1.23$ & $268.2 \pm 18.43$ & $0.07 \pm 0.01$ \\
\hline Saba-soto & $82.1 \pm 1.12$ & $4.7 \pm 0.02$ & $78.3 \pm 1.23$ & $230.1 \pm 19.07$ & $0.10 \pm 0.01$ \\
\hline Saba-tienda & $94.8 \pm 1.12$ & $4.6 \pm 0.02$ & $92.5 \pm 1.23$ & $467.1 \pm 18.40$ & $0.10 \pm 0.01$ \\
\hline Seguifa & $94.8 \pm 1.12$ & $4.6 \pm 0.02$ & $91.6 \pm 1.23$ & $455.6 \pm 18.76$ & $0.11 \pm 0.01$ \\
\hline Sewa & $84.9 \pm 1.12$ & $4.6 \pm 0.02$ & $81.8 \pm 1.23$ & $293.8 \pm 18.31$ & $0.08 \pm 0.01$ \\
\hline Tiandougou & $91.6 \pm 1.12$ & $4.6 \pm 0.02$ & $89.1 \pm 1.23$ & $363.0 \pm 18.90$ & $0.09 \pm 0.01$ \\
\hline Tiandougou-coura & $85.2 \pm 1.12$ & $4.7 \pm 0.02$ & $81.1 \pm 1.23$ & $186.4 \pm 19.60$ & $0.07 \pm 0.01$ \\
\hline$p$-values & $<0.01$ & $<0.01$ & $<0.01$ & $<0.01$ & $<0.01$ \\
\hline LSD & 2.50 & 0.04 & 2.90 & 63.20 & 0.01 \\
\hline \multicolumn{6}{|l|}{ Water sources } \\
\hline Control & $91.0 \pm 0.92$ & $4.7 \pm 0.01$ & $85.1 \pm 1.01$ & $278.1 \pm 16.90$ & $0.08 \pm 0.01$ \\
\hline Distilled & $90.1 \pm 0 ., 92$ & $4.6 \pm 0.01$ & $87.6 \pm 1.01$ & $402.5 \pm 14.70$ & $0.10 \pm 0.01$ \\
\hline Rain & $90.1 \pm 0.92$ & $4.6 \pm 0.01$ & $88.1 \pm 1.01$ & $288.0 \pm 16.55$ & $0.08 \pm 0.01$ \\
\hline River & $91.2 \pm 0.92$ & $4.6 \pm 0.01$ & $89.2 \pm 1.01$ & $434.2 \pm 13.95$ & $0.10 \pm 0.01$ \\
\hline Tap & $91.0 \pm 0.92$ & $4.6 \pm 0.01$ & $89.6 \pm 1.01$ & $351.2 \pm 13.90$ & $0.10 \pm 0.01$ \\
\hline Well & $91.6 \pm 0.92$ & $4.6 \pm 0.01$ & $89.2 \pm 1.01$ & $401.2 \pm 14.41$ & $0.11 \pm 0.01$ \\
\hline$p$-values & 0.40 & $<0.01$ & $<0.01$ & $<0.01$ & $<0.01$ \\
\hline LSD & & 0.03 & 2.30 & 51.60 & 0.01 \\
\hline \multicolumn{6}{|l|}{ Priming duration (h) } \\
\hline 4 & $90.7 \pm 0.92$ & $4.6 \pm 0.01$ & $87.0 \pm 1.01$ & $306.8 \pm 13.21$ & $0.08 \pm 0.01$ \\
\hline 8 & $90.7 \pm 0.92$ & $4.6 \pm 0.01$ & $87.8 \pm 1.01$ & $352.9 \pm 1213$ & $0.11 \pm 0.01$ \\
\hline 12 & $91.5 \pm 0.92$ & $4.5 \pm 0.01$ & $89.6 \pm 1.01$ & $426.2 \pm 12.47$ & $0.10 \pm 0.01$ \\
\hline$p$-values & 0.40 & $<0.01$ & $<0.01$ & $<0.01$ & $<0.01$ \\
\hline LSD & & 0.02 & 1.70 & 36.50 & 0.01 \\
\hline$p$-values for variety $\times$ water sources & 1.00 & 1.00 & 1.00 & 0.99 & 0.18 \\
\hline$p$-values for variety $\times$ duration & 0.80 & 0.70 & 0.90 & 0.57 & 0.05 \\
\hline$p$-values for water $\times$ duration & 0.50 & 0.90 & 0.50 & 0.04 & 0.23 \\
\hline$p$-values for variety $\times$ water $\times$ & 1.00 & 1.00 & 0.28 & 0.99 & 0.54 \\
\hline
\end{tabular}

LSD values at $p \leq 0.05$ according to the fischers' LSD test, GP: Germination percentage, MGT: Mean germination time, GRI: Germination rate index, RVI: Root vigor index, SDW: Seedling dry weight.

\subsubsection{Mean Germination Time (MGT)}

The effect of tepid water on mean germination time of varieties $(p<0.01)$, water sources $(p<0.01)$, and priming duration $(p<0.01)$ were significant. No significant interaction was found among varieties $\times$ water sources $\times$ priming duration (Table 5). Lower values of MGT, which refer to an increase of germination speed, were observed in tepid hydropriming. Among different water sources, tepid $\left(25^{\circ} \mathrm{C}\right)$ significantly improved the mean germination time compared to the unprimed (Table 5). Priming duration in $12 \mathrm{~h}$ revealed that mean germination time was reduced in all water sources compared to the control and $8 \mathrm{~h}$ (Table 5). Deeper analysis showed that different water sources revealed that varieties respond differently while all water sources significantly improved mean germination time compared to control (Table 5).

\subsubsection{Germination Rate Index (GRI)}

Highly significant differences in GRI were found among varieties $(p<0.01)$, water sources $(p<0.01)$, and priming duration treatments $(p<0.01)$. No significant interaction was found among their interaction. The highest GRI was observed with CSM63E 
(98.5\%/day) and Banidoka (96.2\%/day) followed by Saba-tienda (92.5\% day-1) and Seguifa (91.6\%/day). The varieties Nieleni, Sewa, Saba-soto, and Tiandougou-coura were not significantly different among them but were different from Tiandougou (Table 5). Among different water sources, tepid $\left(25^{\circ} \mathrm{C}\right)$ significantly improved the germination rate index compared to the unprimed (Table 5). Priming duration in $12 \mathrm{~h}$ increased germination rate index in all water sources compared to the control and $8 \mathrm{~h}$ (Table 5).

\subsubsection{Root Vigor Index (RVI)}

Root vigor index (RVI) as a function of root length and germination percentage was also significantly affected by varieties $(p=0.01)$, water sources $(p=0.01)$, and priming duration $(p=0.01)$ in tepid water. Significant difference was found between tepid water sources and priming duration $(p<0.04)$ but no interaction was found with varieties $\times$ priming duration and varieties $\times$ water sources $\times$ priming duration. The maximum RVI was observed with variety Banidoka. Varieties Saba-tienda, Seguifa, and CSM63E, were not different but statistically different from other varieties in tepid water (Table 6). In tepid water, varieties respond differently.

Table 6. Root vigor index of 5 water sources under different priming duration in tepid water.

\begin{tabular}{|c|c|c|c|c|}
\hline \multirow{2}{*}{ Water Sources } & \multicolumn{3}{|c|}{ Priming Duration (h) } & \multirow{2}{*}{$\begin{array}{c}\text { Mean RVI for Water } \\
\text { Sources }\end{array}$} \\
\hline & 4 & 8 & 12 & \\
\hline Control & $188.3 \pm 13.21$ & $277.8 \pm 12.96$ & $368.2 \pm 12.47$ & 278.1 \\
\hline Distilled & $362.7 \pm 13.21$ & $375.4 \pm 12.96$ & $469.4 \pm 12.47$ & 402.5 \\
\hline Rain & $286.7 \pm 13.21$ & $267.9 \pm 12.96$ & $309.5 \pm 12.47$ & 288.0 \\
\hline River & $400.7 \pm 13.21$ & $395.5 \pm 12.96$ & $506.4 \pm 12.47$ & 434.2 \\
\hline Tap & $292.2 \pm 13.21$ & $398.0 \pm 12.96$ & $363.3 \pm 12.47$ & 351.2 \\
\hline Well & $300.8 \pm 13.21$ & $382.2 \pm 12.96$ & $520.5 \pm 12.47$ & 401.2 \\
\hline \multirow[t]{2}{*}{ Mean RVI for priming duration } & 305.2 & 349.5 & 422.9 & \\
\hline & $p$-value & SED & LSD & \\
\hline Water sources & $<0.01$ & 26.3 & 51.6 & \\
\hline Priming duration & $<0.01$ & 18.6 & 36.5 & \\
\hline Water sources $\times$ priming duration & 0.04 & 45.5 & 89.3 & \\
\hline
\end{tabular}

$p$-value at $p \leq 0.05$, SED: Standard errors of differences of means, LSD: Least significant differences of means. According to Fischer's LSD post-hoc test.

The maximum RVI was observed in distilled, river, and well water, which were statistically equal. Tap water was not significantly different from distilled and well water but, except rainwater, the remaining water sources improved RVI compared to unprimed seeds. Rainwater was not significantly different from the control in tepid water study.

Priming duration in tepid water at 4,8 , and $12 \mathrm{~h}$, with an increase of priming duration this trait has shown a significant improvement in comparison to control (Table 6). The highest RVI was recorded with $12 \mathrm{~h}$ (RVI of 426.2) statistically different from other priming duration, followed by $8 \mathrm{~h}(\mathrm{RVI}=352.9)$ and when soaked at $4 \mathrm{~h}(306.8)$ in tepid water (Table 6). Interaction effects of water sources treatment $\times$ priming duration on root vigor index were significant. Distilled, river, and well waters in duration $12 \mathrm{~h}$ showed the highest impact on root vigor index (Table 6).

\subsubsection{Seedling Dry Weight (SDW)}

Significant differences in SDW were found among varieties $(p<0.01)$, water sources $(p<0.01)$, and priming duration $(p<0.01)$. There was significant interaction effect of varieties and priming duration $(p<0.05)$ on SDW. Average seedling dry weight was significantly higher in Banidoka and CSM63E. SDW significantly increased with increase of priming duration (Table 7). 
Table 7. Seedling dry weight of 9 sorghum cultivars presoaked under different priming duration in tepid water.

\begin{tabular}{|c|c|c|c|c|}
\hline \multirow[b]{2}{*}{ Variety } & \multicolumn{3}{|c|}{ Priming Duration (h) } & \multirow{2}{*}{ Mean SDW for Varieties } \\
\hline & 4 & 8 & 12 & \\
\hline Banidoka & $0.11 \pm 0.01$ & $0.13 \pm 0.01$ & $0.14 \pm 0.01$ & 0.13 \\
\hline CSM63E & $0.11 \pm 0.01$ & $0.13 \pm 0.01$ & $0.10 \pm 0.01$ & 0.12 \\
\hline Nieleni & $0.06 \pm 0.01$ & $0.07 \pm 0.01$ & $0.06 \pm 0.01$ & 0.07 \\
\hline Saba-soto & $0.10 \pm 0.01$ & $0.12 \pm 0.01$ & $0.08 \pm 0.01$ & 0.10 \\
\hline Saba-tienda & $0.08 \pm 0.01$ & $0.11 \pm 0.01$ & $0.10 \pm 0.01$ & 0.10 \\
\hline Seguifa & $0.08 \pm 0.01$ & $0.12 \pm 0.01$ & $0.12 \pm 0.01$ & 0.11 \\
\hline Sewa & $0.08 \pm 0.01$ & $0.09 \pm 0.01$ & $0.07 \pm 0.01$ & 0.08 \\
\hline Tiandougou & $0.07 \pm 0.01$ & $0.10 \pm 0.01$ & $0.10 \pm 0.01$ & 0.09 \\
\hline Tiandougou-coura & $0.05 \pm 0.01$ & $0.08 \pm 0.01$ & $0.08 \pm 0.01$ & 0.07 \\
\hline \multirow[t]{2}{*}{ Mean SDW for priming duration } & 0.08 & 0.11 & 0.10 & \\
\hline & $p$-value & SED & LSD & \\
\hline Varieties & $<0.01$ & 0.01 & 0.01 & \\
\hline Priming duration & $<0.01$ & 0.01 & 0.01 & \\
\hline Varieties $\times$ priming duration & 0.05 & 0.01 & 0.02 & \\
\hline
\end{tabular}

$p$-value at $p \leq 0.05$, SED: Standard errors of differences of means, LSD: Least significant differences of means according to fishers' LSD test.

There was no difference between priming duration 8 and $12 \mathrm{~h}$. There was no interaction found with varieties $\times$ water sources, water sources $\times$ priming duration and varieties $\times$ water sources $\times$ priming duration (Table 7). In tepid water, the highest SDW was observed with Banidoka $(0.12 \mathrm{~g})$ and CSM63E $(0.12 \mathrm{~g})$, which was however statistically not different from the SDW of Seguifa $(0.11 \mathrm{~g})$. Varieties Saba-Soto and Saba-Tienda $(0.10 \mathrm{~g})$ were not significantly different from Seguifa (Table 7). The lowest SDW was observed with Nieleni and Tiandougou-Coura $(0.07 \mathrm{~g})$. All water sources except rainwater significantly improved SDW compared to unprimed (Table 7). Distilled, river, tap, and well waters were statistically equal in performance on SDW. Rainwater was not statistically different from control. Priming duration in tepid water, $8 \mathrm{~h}$ recorded the highest SDW $(0.11 \mathrm{~g} / \mathrm{plant})$ which was statistically different from 4 and $12 \mathrm{~h}$ soaking. Priming duration from $4 \mathrm{~h}$ was not statistically different to the control (Table 7). The optimum priming duration is $8 \mathrm{~h}$, when increasing after $8 \mathrm{~h}$ the seedling dry weight decreases. Significant interaction was found between varieties $\times$ priming duration, suggesting differential responses to priming duration.

\subsection{Effect of Hot Hydro-Priming on Seed Germination and Seedling Growth Parameters}

\subsubsection{Germination Percentage (GP)}

Varieties $(p<0.01)$ of water sources $(p<0.01)$ were significant in hot water on germination percentage (Table 8). There was no significant interaction effect on germination percentage. Saba-soto, Tiandougou, and Tiandougou-coura recorded the lowest GP in hot water; the highest was recorded in CSM63E, Banidoka, Saba-tienda, and Seguifa (Table 8) in hot water at $70^{\circ} \mathrm{C}$. Sources of water did significantly influence seed germination percentage. The highest germination was recorded in control water at $70{ }^{\circ} \mathrm{C}$ did not increase germination percentage, suggesting an inhibition of some enzymes needed for germination (Table 8).

\subsubsection{Mean Germination Time (MGT)}

Significant difference was found in varieties $(p<0.01)$. There was no significant effect of hydro-priming at $70{ }^{\circ} \mathrm{C}$ on mean germination time with water sources, priming duration, and all interactions (Table 8). Varieties CSM63E, Banidoka, and Saba-tienda (4.5 days) showed reduced mean germination time compared to Nieleni, Saba-soto, Seguifa, Sewa, Tiandougou, and Tiandougou-coura (4.6 days). The highest MGT was recorded in Saba-soto (4.7 days). Varieties respond differently to heated water sources at $70{ }^{\circ} \mathrm{C}$ (Table 8 ). 
Table 8. Effect of water priming at different durations and with water from different sources on seed germination and growth parameters of nine varieties of sorghum in hot water.

\begin{tabular}{|c|c|c|c|c|c|}
\hline \multirow{2}{*}{$\begin{array}{c}\text { Treatments } \\
\text { Variety }\end{array}$} & \multicolumn{5}{|c|}{ Growth Parameters } \\
\hline & GP & MGT & GRI & RVI & SDW \\
\hline Banidoka & $98.3 \pm 1.12$ & $4.5 \pm 0.02$ & $488.3 \pm 1.23$ & $226.0 \pm 15.30$ & $0.10 \pm 0.01$ \\
\hline CSM63E & $98.3 \pm 1.12$ & $4.5 \pm 0.02$ & $485.6 \pm 1.23$ & $292.7 \pm 18.90$ & $0.07 \pm 0.01$ \\
\hline Nieleni & $83.2 \pm 1.12$ & $4.6 \pm 0.02$ & $427.3 \pm 1.23$ & $130.9 \pm 18.43$ & $0.06 \pm 0.01$ \\
\hline Saba-soto & $77.8 \pm 1.12$ & $4.7 \pm 0.02$ & $457.0 \pm 1.23$ & $80.6 \pm 19.07$ & $0.06 \pm 0.01$ \\
\hline Saba-tienda & $90.9 \pm 1.12$ & $4.5 \pm 0.02$ & $426.7 \pm 1.23$ & $219.5 \pm 18.40$ & $0.05 \pm 0.01$ \\
\hline Seguifa & $92.1 \pm 1.12$ & $4.6 \pm 0.02$ & $454.1 \pm 1.23$ & $168.2 \pm 18.76$ & $0.06 \pm 0.01$ \\
\hline Sewa & $85.4 \pm 1.12$ & $4.6 \pm 0.02$ & $460.0 \pm 1.23$ & $128.5 \pm 18.31$ & $0.06 \pm 0.01$ \\
\hline Tiandougou & $78.7 \pm 1.12$ & $4.6 \pm 0.02$ & $438.0 \pm 1.23$ & $79.4 \pm 18.90$ & $0.03 \pm 0.01$ \\
\hline Tiandougou-coura & $78.2 \pm 1.12$ & $4.6 \pm 0.02$ & $461.2 \pm 1.23$ & $63.0 \pm 18.60$ & $0.03 \pm 0.01$ \\
\hline$p$-values & $<0.01$ & $<0.01$ & 0.96 & $<0.01$ & $<0.01$ \\
\hline LSD & 4.1 & 0.03 & 111.5 & 48.8 & 0.01 \\
\hline \multicolumn{6}{|l|}{ Water sources } \\
\hline Control & $91.6 \pm 0.92$ & $4.6 \pm 0.01$ & $451.5 \pm 0.01$ & $122.7 \pm 16.90$ & $0.04 \pm 0.01$ \\
\hline Distilled & $86.0 \pm 0.92$ & $4.6 \pm 0.01$ & $456.6 \pm 0.01$ & $158.3 \pm 14.70$ & $0.06 \pm 0.01$ \\
\hline Rain & $81.5 \pm 0.92$ & $4.6 \pm 0.01$ & $449.4 \pm 0.01$ & $109.3 \pm 16.55$ & $0.05 \pm 0.01$ \\
\hline River & $85.8 \pm 0.92$ & $4.6 \pm 0.01$ & $453.9 \pm 0.01$ & $185.3 \pm 13.95$ & $0.07 \pm 0.01$ \\
\hline Tap & $87.6 \pm 0.92$ & $4.6 \pm 0.01$ & $458.1 \pm 0.01$ & $181.9 \pm 13.90$ & $0.07 \pm 0.01$ \\
\hline Well & $89.5 \pm 0.92$ & $4.6 \pm 0.01$ & $462.8 \pm 0.01$ & $168.4 \pm 16.40$ & $0.06 \pm 0.01$ \\
\hline$p$-values & $<0.01$ & 0.80 & 1.00 & $<0.01$ & $<0.01$ \\
\hline LSD & 3.3 & 0.03 & 91.0 & 39.9 & 0.01 \\
\hline \multicolumn{6}{|l|}{ Priming duration (min.) } \\
\hline 10 & $87.3 \pm 0.92$ & $4.6 \pm 0.01$ & $449.4 \pm 0.01$ & $101.9 \pm 13.21$ & $0.05 \pm 0.01$ \\
\hline 20 & $87.1 \pm 0.92$ & $4.6 \pm 0.01$ & $459.2 \pm 0.01$ & $170.7 \pm 12.13$ & $0.06 \pm 0.01$ \\
\hline 30 & $86.6 \pm 0.92$ & $4.6 \pm 0.01$ & $457.5 \pm 0.01$ & $190.3 \pm 12.47$ & $0.06 \pm 0.01$ \\
\hline$p$-values & 0.83 & 0.33 & 0.95 & $<0.01$ & 0.01 \\
\hline LSD & 2.4 & 0.02 & 64.4 & 28.2 & 0.01 \\
\hline
\end{tabular}

LSD values at $p \leq 0.05$ GP: Germination percentage, MGT: Mean germination time, RVI: Root vigor index, SDW: Seedling dry weight.

\subsubsection{Germination Rate Index (GRI)}

No significant difference was found in hydro-priming at $70{ }^{\circ} \mathrm{C}$ on germination rate index with varieties, water sources, priming duration, and their interaction (Table 9).

Table 9. Effect of water priming at different durations and with water from different sources on seed germination and growth parameters of nine varieties of sorghum in hot water.

\begin{tabular}{ccccccc}
\hline & \multicolumn{5}{c}{ Growth Parameters } \\
\hline Treatments Variety & GP & MGT & GRI & SVI & RVI & SDW \\
\hline Banidoka & $98.3 \pm 1.12$ & $4.5 \pm 0.02$ & $488.3 \pm 1.23$ & $537.0 \pm 24.23$ & $226.0 \pm 15.30$ & $0.10 \pm 0.01$ \\
CSM63E & $98.3 \pm 1.12$ & $4.5 \pm 0.02$ & $485.6 \pm 1.23$ & $582.0 \pm 30.03$ & $292.7 \pm 18.90$ & $0.07 \pm 0.01$ \\
Nieleni & $83.2 \pm 1.12$ & $4.6 \pm 0.02$ & $427.3 \pm 1.23$ & $267.9 \pm 29.30$ & $130.9 \pm 18.43$ & $0.06 \pm 0.01$ \\
Saba-soto & $77.8 \pm 1.12$ & $4.7 \pm 0.02$ & $457.0 \pm 1.23$ & $210.0 \pm 30.29$ & $80.6 \pm 19.07$ & $0.06 \pm 0.01$ \\
Saba-tienda & $90.9 \pm 1.12$ & $4.5 \pm 0.02$ & $426.7 \pm 1.23$ & $423.5 \pm 29.16$ & $219.5 \pm 18.40$ & $0.05 \pm 0.01$ \\
Seguifa & $92.1 \pm 1.12$ & $4.6 \pm 0.02$ & $454.1 \pm 1.23$ & 306.926 .62 & $168.2 \pm 18.76$ & $0.06 \pm 0.01$ \\
Sewa & $85.4 \pm 1.12$ & $4.6 \pm 0.02$ & $460.0 \pm 1.23$ & $268.9 \pm 28.94$ & $128.5 \pm 18.31$ & $0.06 \pm 0.01$ \\
Tiandougou & $78.7 \pm 1.12$ & $4.6 \pm 0.02$ & $438.0 \pm 1.23$ & $158.1 \pm 32.60$ & $79.4 \pm 18.90$ & $0.03 \pm 0.01$ \\
Tiandougou-coura & $78.2 \pm 1.12$ & $4.6 \pm 0.02$ & $461.2 \pm 1.23$ & $147.3 \pm 33.80$ & $63.0 \pm 18.60$ & $0.03 \pm 0.01$ \\
p-values & $<0.01$ & $<0.01$ & 0.96 & $<0.01$ & $<0.01$ & $<0.01$ \\
LSD & 4.1 & 0.03 & 111.5 & 92.6 & 48.8 & 0.01 \\
Water sources & & & & & &
\end{tabular}


Table 9. Cont.

\begin{tabular}{|c|c|c|c|c|c|c|}
\hline \multirow[b]{2}{*}{ Treatments Variety } & \multicolumn{6}{|c|}{ Growth Parameters } \\
\hline & GP & MGT & GRI & SVI & RVI & SDW \\
\hline Control & $91.6 \pm 0.92$ & $4.6 \pm 0.01$ & $451.5 \pm 0.01$ & $237.2 \pm 26.32$ & $122.7 \pm 16.90$ & $0.04 \pm 0.01$ \\
\hline Distilled & $86.0 \pm 0.92$ & $4.6 \pm 0.01$ & $456.6 \pm 0.01$ & $343.9 \pm 23.29$ & $158.3 \pm 14.70$ & $0.06 \pm 0.01$ \\
\hline Rain & $81.5 \pm 0.92$ & $4.6 \pm 0.01$ & $449.4 \pm 0.01$ & $239.6 \pm 25.92$ & $109.3 \pm 16.55$ & $0.05 \pm 0.01$ \\
\hline River & $85.8 \pm 0.92$ & $4.6 \pm 0.01$ & $453.9 \pm 0.01$ & $397.6 \pm 22.32$ & $185.3 \pm 13.95$ & $0.07 \pm 0.01$ \\
\hline Tap & $87.6 \pm 0.92$ & $4.6 \pm 0.01$ & $458.1 \pm 0.01$ & $374.2 \pm 21.99$ & $181.9 \pm 13.90$ & $0.07 \pm 0.01$ \\
\hline Well & $89.5 \pm 0.92$ & $4.6 \pm 0.01$ & $462.8 \pm 0.01$ & $342.0 \pm 22.39$ & $168.4 \pm 16.40$ & $0.06 \pm 0.01$ \\
\hline$p$-values & $<0.01$ & 0.80 & 1.00 & $<0.01$ & $<0.01$ & $<0.01$ \\
\hline LSD & 3.3 & 0.03 & 91.0 & 75.6 & 39.9 & 0.01 \\
\hline \multicolumn{7}{|l|}{$\begin{array}{l}\text { Priming duration } \\
\text { (min.) }\end{array}$} \\
\hline 10 & $87.3 \pm 0.92$ & $4.6 \pm 0.01$ & $449.4 \pm 0.01$ & $206.3 \pm 28.32$ & $101.9 \pm 13.21$ & $0.05 \pm 0.01$ \\
\hline 20 & $87.1 \pm 0.92$ & $4.6 \pm 0.01$ & $459.2 \pm 0.01$ & $350.6 \pm 24.32$ & $170.7 \pm 12.13$ & $0.06 \pm 0.01$ \\
\hline 30 & $86.6 \pm 0.92$ & $4.6 \pm 0.01$ & $457.5 \pm 0.01$ & $410.3 \pm 25.32$ & $190.3 \pm 12.47$ & $0.06 \pm 0.01$ \\
\hline$p$-values & 0.83 & 0.33 & 0.95 & $<0.01$ & $<0.01$ & 0.01 \\
\hline LSD & 2.4 & 0.02 & 64.4 & 53.4 & 28.2 & 0.01 \\
\hline
\end{tabular}

LSD values at $p \leq 0.05$ GP: Germination percentage, MGT: Mean germination time, GI: Germination index, SVI: Seedling vigor index, RVI: Root vigor index, SDW: Seedling dry weight.

\subsubsection{Root Vigor Index (RVI)}

Significant difference was found in varieties $(p<0.01)$, water sources $(p<0.01)$, and priming duration $(p<0.01)$ on root vigor index. There was no significant interaction of hydro-priming at $70{ }^{\circ} \mathrm{C}$ on root vigor index. Varieties CSM63E, Banidoka, and Saba-tienda recorded the highest RVI while the lowest was found in Tiandougou and Tiandougou-coura (Table 9). Varieties Nieleni, Sewa, and Seguifa were not significantly different but were statistically different from Tiandougou and Tiandougou-coura. River, tap, and well water at $70{ }^{\circ} \mathrm{C}$ were significantly different from rainwater, but were not significantly different from distilled water. Distilled and rainwater were not significantly different from the unprimed control. Priming duration increased RVI from 10 to $20 \mathrm{~mm}$. There was no significant effect of priming duration 20 and $30 \mathrm{mn}$ in water at $70{ }^{\circ} \mathrm{C}$ (Table 9).

\subsubsection{Seedling Dry Weight (SDW)}

The seedling dry weight significantly varied with varieties $(p<0.01)$, water sources $(p<0.01)$, and priming duration $(p<0.01)$ in water at $70{ }^{\circ} \mathrm{C}$. There was no significant interaction of hydro-priming at $70^{\circ} \mathrm{C}$ on seedling dry weight (Table 9). Varieties CSM63E and Banidoka recorded the highest SDW while the lowest was found in varieties Nieleni and Tiandougou-coura (Table 9). Varieties Nieleni, Saba-soto, Sewa, and Seguifa were not significantly different but were statistically higher compared to Tiandougou and Tiandougou-coura (Table 9). All water sources significantly improved seedling dry weight compared to unprimed control in water at $70{ }^{\circ} \mathrm{C}$. Distilled, river, tap, and well waters were significantly different from rainwater which was also different from unprimed control (Table 9). Priming duration of 10, 20, and $30 \mathrm{mn}$ in water at $70{ }^{\circ} \mathrm{C}$ increased seedling dry weight compared to unprimed control. Priming duration 20 and $30 \mathrm{mn}$ was significantly higher than $10 \mathrm{mn}$ soaking in water $70^{\circ} \mathrm{C}$ (Table 9), but which was not statistically different between themselves. Seed primed in water at $70^{\circ} \mathrm{C}$ during 10, 20, and 30 min was not significantly different from tepid water, suggesting that hydro-priming in tepid or water at $70{ }^{\circ} \mathrm{C}$ leads to similar seed germination levels.

\section{Discussion}

In their dormant state, seeds are characteristically low in moisture level and therefore relatively inactive. However, moisture triggers germination as it activates enzymes, breakdown, translocation, and use of reserve storage material: hence in general, findings 
showed that hydro-priming durations enhanced seedling emergence percentage and reduced emergence time. Better seed emergence through hydro-priming suggests that proper priming duration can improve optimum plant establishment of sorghum in the field. Rapid emergence of seedlings could lead to the production of vigorous plants [37].

Given that water, through interacting with all the components of natural landscape and being influenced by natural and man-made factors, is enriched by a wide gamut of various substances in gaseous, solid, and liquid states, this creates an enormous variability of natural water types from the perspective of their chemical composition [37]. In terms of varieties performance, Banidoka and CSM63E were the best in either hydro-primed in tepid water $\left(25^{\circ} \mathrm{C}\right)$ or heated water at $70^{\circ} \mathrm{C}$, followed by Saba-tienda mainly in tepid water $\left(25^{\circ} \mathrm{C}\right)$. With regards to priming duration in water heated at $70^{\circ} \mathrm{C}, 30 \mathrm{~min}$ recorded the highest effect compared to other treatments on RVI and SDW.

Compared to the unprimed treatment (control), the germination percentage, germination time, germination rate index, seedling root index, and seedling dry weight increased considerably after sorghum seeds had been primed with different sources of water. The findings showed that the improvements of germination and seedling growth as expressed by all monitored parameters were reduced when soaked in rainwater for most of the parameters including RVI, SDW, etc. (Table 5, Table 8, and Table 9).

Natural water is a dynamic chemical system containing in its composition a complex group of gases, mineral organic substances in the form of true solutions, and suspended and colloidal matter as well [38]. The differences in their composition explain why sorghum seed priming with various sources/types of water differently influenced the seed germination performance. Indeed, after eight days, remarkable differences were observed for seed germination and seedling growth of CSM63E, Banidoka, Saba-tienda, and Seguifa. Germination and early seedling establishment are critical stages, which can affect both quality and seedling growth parameters [5]. This is suggesting some inhibition effect on seed and seedling growth parameters. Due to their imbibition in water solutions, seeds benefit from permanent and sufficient moisture thus take a short time to germinate; however, non-primed seeds have to obtain from soil moisture their imbibition, which may lead to longer time for their germination if soil moisture is not sufficient. This explains the increased germination performance with the hydro-priming technique [39].

It is evident that hydro-primed seeds exhibit activation of cellular defense responses, due to which they can better tolerate subsequent biotic or abiotic stresses in the field [39]. Seed priming enhances speed and uniformity of germination [21]. This can extend many biochemical modifications which are basically needed for starting germination process viz. dormancy breaking, hydrolysis, enzyme creation, and seed imbibition [39]. Thus, seed priming could contribute to facilitating emergence phage with vigorous root and shoot of sorghum which is very important at the beginning of the rainy season in the Sahelian zone. A deep and thick root system is helpful for extracting water from considerable depths [40]. Similar findings have been reported on the improved germination of sunflower cultivars through accelerated imbibition by seed priming [41].

Seed priming significantly increased a series of seedling performance parameters such as the GP, MGT, GRI, RVI, and SDW of sorghum. The improvement of these parameters might be due to the fact that the seeds soaked in water had rapid translocation of nutrients after hydrolysis of the cotyledon reserves to growing seedling. Additionally, primed seed known to be closely associated with their high imbibition rate and mtDNA damaged reparation, which could be the reason for the increased germination percentage. When compared with different sources of water, distilled, river, tap, and well water of all durations showed greater influence on final germination percentage seedling development. River and well water showed high influence on seed and seedling growth parameters suggesting favorable $\mathrm{pH}$ at germination [42]. During seed germination, various stored substrates are reactivated, repaired if damaged, and transformed into new building materials necessary for the initial growth of the embryo, its subsequent growth, and seedling establishment in its natural habitat [43]. 
The improvement in seed germination and seedling development due to seed priming treatment is in line with previous research work [5,31,44], and reported that both fresh and hot water primed seeds showed significant increase in germination performance.

As far as we know it is the first time in Mali that physicochemical composition of well water can boost sorghum seedling germination and development. The results show also that tepid hydro-priming treatment was comparatively superior to heated at $70{ }^{\circ} \mathrm{C}$ in root vigor index among all water sources applications. These findings are in agreement with previous studies $[43,45,46]$. Several researchers reported the positive effect of hydropriming on seedling emergence rate, seedling establishment, early vigor, and the faster development of the seedling [47].

Various seed priming techniques using different sources of water, and either tepid or water heated at $70{ }^{\circ} \mathrm{C}$ can significantly improve seed germination and seedling plant development of sorghum varieties, although the overall response varied with the different sources of water, priming duration, and varieties. All the water sources improved seed germination and seedlings growth parameters compared to control, but well, distilled, river, and tap water were better than rainwater which suggest the presence of some element such as $\mathrm{Cu}$ and $\mathrm{Zn}$ which inhibits seed germination and growth (Table 4).

\section{Conclusions}

The results indicate that seed germination and various seedling growth parameters of sorghum varieties were improved by tepid water and hot hydro-priming with various water sources and under different priming durations. Tepid or hot water increased seed germination percentage, mean germination time, seedling growth rate, root vigor index, and seedling dry weight compared to the unprimed control seeds of all nine sorghum cultivars. Our results showed that hydro-priming in tepid or hot water shows to be a promising technique to improve seed germination and seedling growth parameters which needs to be confirmed in field trials. River and well water sources were the most promising sources in this study. The $8 \mathrm{~h}$ priming duration with fresh water is the most promising option, although seeds have to be immediately sown to benefit from the hydrated effect. The promising duration in hot water was $30 \mathrm{~min}$ which have significantly impacted germination percentage, mean germination time and germination rate index. When immediate sowing is possible, tepid or hot hydro-priming of sorghum seed is recommended as an effective way to reduce risk of crop failure regularly resulting from the unpredictable rainfall situation in Mali. The varieties Banidoka, CSM63E and Saba-tienda could be recommended in an integrated drought and heat management option for crop establishment failure in semi-arid zones of Mali and elsewhere.

Author Contributions: Conceptualization, all authors; methodology, S.D., R.B.Z., J.P.A.L.; validation, R.B.Z., J.P.A.L., J.P.T.; formal analysis, S.D.; investigation, S.D.; resources, all authors.; data curation, S.D., J.P.T., J.P.T.; writing—original draft preparation, S.D.; writing-review and editing, R.B.Z., J.P.A.L.; supervision, R.B.Z., J.P.A.L., J.P.T., A.C.; project administration, J.P.A.L., J.P.T.; funding acquisition, S.D., J.P.A.L., All authors have read and agreed to the published version of the manuscript.

Funding: This research was fully funded by West African Science Service Center for Climate Change and Adapted Land Use (WASCAL) as part of the first author PhD research work. For details, please visit https: / / wascal.org (accessed on 3 March 2021). We also acknowledge the support of the CGIAR/CCAFS Program funded through CGIAR donors (please visit https: / /ccafs.cgiar.org/donors, (accessed on 3 March 2021)).

Institutional Review Board Statement: Not applicable.

Informed Consent Statement: Not applicable.

Data Availability Statement: Not applicable.

Acknowledgments: The authors express their gratitude to the University of Cape Coast, IPR/IFRA of Katibougou, ZEF and ICRISAT for all technical support. We also would like to gratefully acknowledge the facilities provided by the Agricultural Research Station of Cinzana, Institut d'Economie 
Rurale (IER) of Mali in this study. The assistance of Technicians in field measurements is gratefully acknowledged. The authors are in particular grateful to Guido Luechters from ZEF for his support in all statistical analyses conducted by the corresponding author.

Conflicts of Interest: The authors declare no conflict of interest.

\section{References}

1. Tian, Y.; Guan, B.; Zhou, D.; Yu, J.; Li, G.; Lou, Y. Responses of Seed Germination, Seedling Growth, and Seed Yield Traits to Seed Pretreatment in Maize (Zea mays L.). Sci. World J. 2014, 2014, 1-8. [CrossRef]

2. Dembélé, S. Developing Cultivation Practices to Combat early Drought Challenges: The Case of Sorghum in Mali. Ph.D. Thesis, University of Cape Coast, Cape Coast, Ghana, 2016.

3. Hamidreza, K.; Earl, H.; Sabzevari, S.; Yanegh, J. Effects of Osmo-Hydropriming and Drought Stress on Seed Germination and Seedling Growth of Rye (Secale Montanum). ProEnviron. Promediu 2013, 6, 496-507.

4. Soleimanzadeh, H. Effect of seed priming on germination and yield of corn. Int. J. Agric. Crop Sci. 2013, 5, 366-369.

5. Yanrong, W.; Jianquan, Z.; Huixia, L.; Xiaowen, H. Physiological and ecological responses of alfalfa and milkvetch seed to PEG priming. Acta Ecol. Sin. 2003, 24, 402-408.

6. Lutts, S.; Benincasa, P.; Wojtyla, L.; Kubala, S.; Pace, R.; Lechowska, K.; Quinet, M.; Garnczarska, M. Seed Priming: New Comprehensive Approaches for an Old Empirical Technique. New Challenges Seed Biol. Basic Transl. Res. Driv. Seed Technol. 2016. [CrossRef]

7. Heydecker, W.; Higgins, J.; Gulliver, R.L. Accelerated Germination by Osmotic Seed Treatment. Nature 1973, 246, 42-44. [CrossRef]

8. Taylor, A.G.; Prusinski, J.; Hill, H.J.; Dickson, M.D. Influence of seed hydration on seedling performance. Horttechnology 1992, 2, 336-344. [CrossRef]

9. Passam, H.C.; Kakouriotis, D. The effects of osmoconditioning on the germination, emergence and early plant growth of cucumber under saline conditions. Sci. Hortic. 1994, 57, 233-240. [CrossRef]

10. Seyed Sharifi, R.; Khavazi, K. Effects of seed priming with Plant Growth Promoting Rhizobacteria (PGPR) on yield and yield attribute of maize (Zea mays L.) hybrids. J. Food Agric. Environ. J. Food Agric. Environ. 2005, 99, 496-500.

11. Souza, M.O.; Pelacani, C.R.; Willems, L.A.; Castro, R.D.; Hilhorst, H.W.; Ligterink, W. Effect of osmopriming on germination and initial growth of physalis angulata L. under salt stress and on expression of associated genes. An. Acad. Bras. Cienc. 2016, 88, 503-516. [CrossRef] [PubMed]

12. Gupta, S.; Narzary, R. Aquatic insect community of lake, Phulbari anua in Cachar, Assam. J. Environ. Biol. 2013, 34, 591-597. [PubMed]

13. Matsushima, K.-I.; Sakagami, J.-I. Effects of Seed Hydropriming on Germination and Seedling Vigor during Emergence of Rice under Different Soil Moisture Conditions. Am. J. Plant Sci. 2013, 4, 1584-1593. [CrossRef]

14. Mehri, S. Effect of Seed Priming on Emergence, Yield and Storability of Soybean. Am. J. Agric. Environ. Sci. 2005, 15, 399-403.

15. Parera, C.A.; Cantliffe, D.J. Dehydration Rate after Solid Matrix Priming Alters Seed Performance of Shrunken-2 Corn. J. Am. Soc. Hortic. Sci. 1994, 119, 629-635. [CrossRef]

16. Marwat, K.B.; Khan, M.A.; Arif, M.; Al, E.T. Seed Priming Improves Emergance and Yield of Soybean. Pakistan J. Bot. 2008, 40, $1169-1177$.

17. Kaya, M.D.; Okçu, G.; Atak, M.; Çikili, Y. \& Kolsarici, Ö. Seed treatments to overcome salt and drought stress during germination in sunflower (Helianthus annuus L.). Eur. J. Agron. 2006, 24, 291-295.

18. Pazhanisamy, S.; Narayanan, A.; Sridevi, V.; Singh, A.; Singh, A.K. Effect of Seed Priming Practices on Dry Matter Production, Yield and Yield Attributes of Aerobic Rice in Coastal Deltaic Region of Karaiakal. Eur. J. Nutr. Food Saf. 2020, 12, 79-83. [CrossRef]

19. Ahammad, K.U.; Rahman, M.M.; Ali, M.R. Effect of Hydropriming method on maize (Zea mays) seedling emergence Bangladesh. J. Agric. Res. 2014, 39, 143-150.

20. Singh, B.G. Effect of hydration-dehydration seed treatments on vigour and yield of sunflower. Indian J. Plant Physiol. 1995, 38, 66-68.

21. Jamil, M.; Rha, E.S. Gibberellic Acid enhance seed water uptake, germination and early seedling growth in sugar beet under salt stress. Pak J. Biol. Sci. 2007, 10, 654-658. [CrossRef]

22. Harris, D.; Pathan, A.; Gothkar, P.; Joshi, A.; Chivasa, W.; Nyamudeza, P. On-farm seed priming: Using participatory methods to revive and refine a key technology. Agric. Syst. 2001, 69, 151-164. [CrossRef]

23. Association of Official Seed Analysis (AOSA). Rules for testing seeds. J. Seed Technol. 1991, 12, 18-19.

24. Association of Official Seed Analysis (AOSA). Seed Vigor Testing Handbook; Contribution No. 32 to the Handbook on Seed Testing; AOSA: Ithaca, NY, USA, 1983.

25. Ali, S.A.; Idris, A.Y. Germination and Seedling Growth of Pearl Millet (Pennisetum glaucum L.) Cultivars under Salinity Conditions. Int. J. Plant Sci. Ecol. 2015, 1, 1-5.

26. Ellis, R.H.; Covell, S.; Roberts, E.H.; Summerfield, R.J. The Influence of Temperature on Seed Germination Rate in Grain Legumes. J. Exp. Bot. 1986, 37, 1503-1515. [CrossRef]

27. Moradi, A.; Sharif Zadeh, F.; Tavakoli Afshari, R.; Maali Amir, R. The effects of priming and drought stress treatments on some physiological characteristics of tall wheat grass (Agropyron elangatum) seeds. Int. J. Agric. Crop Sci. 2012, 4, 596-603.

28. Sepehri, A.; Najari, S.; Rouhi, H.R. Seed Priming to Overcome Salinity Stress in Persian Cultivars of Alfalfa (Medicago sativa L.). Not. Sci. Biol. 2015, 7, 96-101. [CrossRef]

29. AGRA. Catalogue Official des Especes et Varieties, Tome I Cultures Vivrieres; AGRA: Rome, Italy, 2013.

30. Dembélé, S. Rapport D'activites; Agricultural Reseach Station of Cinzana, Cinzana, Mali, 2015. Unpublished. 
31. Basra, S.; Farooq, M.; Tabassam, R.; Ahmad, N. Physiological and biochemical aspects of pre-sowing seed treatments in fine rice (Oryza sativa L.). Seed Sci. Technol. 2005, 33, 623-628. [CrossRef]

32. Nelson, L.R.; Hsu, K.H. Effects of Leachate Accumulation During Hydration in a Thermalscrew Blancher on the Water Absorption and Cooked Texture of Navy Beans. J. Food Sci. 1985, 50, 782-788. [CrossRef]

33. Dezfuli, P.M.; Sharif-Zadeh, F.; Janmohammadi, M. Influence of Priming Techniques on Seed Germination Behavior of Maize inbred lineS (Zea mays L.). ARPN J. Agric. Biol. Sci. 2008, 3, 22-25.

34. Duzgunes, O.; Kesici, T.; Gurbuz, F. Statistical Methods I; Ankara University, Agricultural Engineering Faculty Press: Ankara, Turkey, 1983; 229p.

35. Shaban, M. Effect of water and temperature on seed germination and emergence as a seed hydrothermal time model. Int. J. Adv. Biol. Biomed. Res. 2013, 1, 1686-1691.

36. Ghassemi-Golezani, K.; Chadordooz-Jeddi, A.; Zafarani-Moattar, P. Influence of salt-priming on mucilage yield of Isabgol (Plantago ovata Forsk) under salinity stress. J. Med. Plants Res. 2011, 5, 3236-3241.

37. Nikanorov, A.M.; Brazhnikova, L.V. Water Chemical Composition of rivers, Lakes and Wetlands. Types Prop. Water 2009, 2, 42-80.

38. Imtiaz Sudozai, M.; Tunio, S.; Rajpar, I. Seedling Establishment and Yield of Maize under Different SEed Priming Periods and available soil moisture. Sarhad J. Agric. 2013, 29, 515-528.

39. Nakaune, M.; Tsukazawa, K.; Uga, H.; Asamizu, E.; Imanishi, S.; Matsukura, C.; Ezura, H. Low sodium chloride priming increases seedling vigor and stress tolerance to Ralstonia solanacearum in tomato. Plant Biotechnol. 2012, 29, 9-18. [CrossRef]

40. Tekle, A.T.; Alemu, M.A. Drought Tolerance Mechanisms in Field Crop s. World J. Biol. Med. Sci. 2016, 3, 15-39.

41. Farahani, H.A.; Moaveni, P.; Maroufi, K. Effect of thermopriming on germination of cowpea (Vigna sinensis L.). Adv. Environ. Biol. 2011, 5, 1668-1674.

42. Carter, M.R.; Sanderson, J.B.; MacLeod, J.A. Influence of compost on the physical properties and organic matter fractions of a fine sandy loam throughout the cycle of a potato rotation. Can. J. Soil Sci. 2004, 84, 211-218. [CrossRef]

43. Koller, D.; Hadas, A. Water Relations in the Germination of Seeds. In Physiological Plant Ecology II; Springer: Berlin/Heidelberg, Germany, 1982; pp. 401-431.

44. Murungu, F.; Chiduza, C.; Nyamugafata, P.; Clark, L.; Whalley, W.; Finch-Savage, W. Effects of 'on-farm seed priming' on consecutive daily sowing occasions on the emergence and growth of maize in semi-arid Zimbabwe. Field Crop. Res. 2004, 89, 49-57. [CrossRef]

45. Ashraf, M.; Foolad, M. Pre-sowing seed treatment-A shotgun approach to improve germination, plant growth, and crop yield under saline and non-saline conditions. Adv. Agron. 2005, 88, 223-271.

46. Kibite, S.; Harker, K.N. Effects of seed hydration on agronomic performance of wheat, barley and oats in central Alberta. Can. J. Plant Sci. 1991, 71, 515-518. [CrossRef]

47. Damalas, C.A.; Koutroubas, S.D.; Fotiadis, S. Hydro-priming Effects on Seed Germination and Field Performance of Faba Bean in Spring Sowing. Agriculture 2019, 9, 201. [CrossRef] 